\title{
Professional exhaustion, quality and intentions among family health nurses
}

\author{
Esgotamento profissional, qualidade e intenções entre enfermeiros de saúde da família \\ Agotamiento profesional, calidad e intenciones entre enfermeros de salud de la familia
}

\section{Vera Regina Lorenz', Marcos Oliveira Sabino", Heleno Rodrigues Corrêa Filho"II}

' Universidade Federal de São Carlos, Center of Biological and Health Sciences, Medical Department. São Carlos, São Paulo, Brazil. "Pontifícia Universidade Católica de Campinas, Center of Life Sciences, Medical School. Campinas, São Paulo, Brazil.

I"' Universidade de Brasília, Department of Collective Health. Brasília, Distrito Federal, Brazil.

How to cite this article:
Lorenz VR, Sabino MO, Correa Filho HR. Professional exhaustion, quality and intentions
among family health nurses. Rev Bras Enferm [Internet]. 2018;71(Suppl 5):2295-301.
[Thematic Issue: Mental health] DOI: http://dx.doi.org/10.1590/0034-7167-2016-0510

Submission: 09-16-2016

Approval: 07-22-2017

\begin{abstract}
Objective: to analyze how family health nurses assess quality of care; check if they have any intention of leaving their current job and nursing; estimate prevalence of professional exhaustion; and correlate these variables. Method: cross-sectional and correlational study with 198 nurses. The Maslach Burnout Inventory was applied, as it has questions for characterizing nurses, assessing perception on quality of care and of material and human resources, and verifying intention of leaving current work and nursing. Results: most nurses assess quality of care as good, 28.0\% present emotional exhaustion, there is intention of leaving current work and nursing. Conclusions: family health nurses experience professional exhaustion, which in turn presents correlation with decreased quality of care and increased intentions of leaving current work and nursing.
\end{abstract}

Descriptors: Quality of Health Care; Intention; Burnout, Professional; Nursing; Occupational Health Services.

\section{RESUMO}

Objetivo: analisar como enfermeiros de saúde da família avaliam qualidade do cuidado; verificar se têm intenção de deixar o trabalho atual e a enfermagem; estimar prevalência de esgotamento profissional e correlacionar variáveis. Método: estudo transversal e correlacional com 198 enfermeiros. Foi utilizado o Maslach Burnout Inventory, questões para caracterizar os enfermeiros, para avaliar percepção sobre a qualidade do cuidado e de recursos materiais e humanos e para verificar intenções de deixar o trabalho atual e a enfermagem. Resultados: a maioria dos enfermeiros avalia a qualidade do cuidado como boa, 28,0\% apresenta exaustão emocional, há intenção de deixar o trabalho atual e a enfermagem. Conclusão: enfermeiros de saúde da família vivenciam esgotamento profissional que apresenta correlação com diminuição da qualidade do cuidado e com aumento das intenções de deixar o trabalho atual e a enfermagem.

Descritores: Qualidade da Assistência à Saúde; Intenção; Esgotamento Profissional; Enfermagem; Serviços de Saúde do Trabalhador.

\section{RESUMEN}

Objetivo: analizar como enfermeros de salud de la familia evalúan la calidad del cuidado; verificar si tienen intención de dejar el trabajo actual y la enfermería; estimar la prevalencia de agotamiento profesional y correlacionar variables. Método: estudio transversal y correlacional con 198 enfermeros. Se utilizó el Maslach Burnout Inventory, cuestiones para caracterizar a los enfermeros, para evaluar percepción sobre la calidad del cuidado y de recursos materiales y humanos, así como para verificar intenciones de dejar el trabajo actual y la enfermería. Resultados: la mayoría de los enfermeros evalúa la calidad del cuidado como buena, el 28,0\% presenta agotamiento emocional, con intención de dejar el trabajo actual y la enfermería. Conclusión: enfermeros de salud de la familia experimentan agotamiento profesional que presenta correlación con disminución de la calidad del cuidado y con aumento de las intenciones de dejar el trabajo actual y la enfermería.

Descriptores: Calidad de La Atención de Salud; Intención; Agotamiento Profesional; Enfermería; Servicios de Salud del Trabajador. 


\section{INTRODUCTION}

This study is based on the theoretical framework of environments favorable to nursing practice, elaborated by the International Council of Nurses and characterized by innovative political frameworks centered on recruitment and retention of nurses, training and promotion strategies, adequate compensation for nurses, recognition programs for the work conducted, sufficient equipment and materials, and a safe work environment.

The working environment of family health nurses does not always offer favorable conditions for nursing practice. The association between two models of assistance in primary health care (APS), a traditional one focused on biomedicine, and the other with focus on the family health strategy (ESF), imposed the extension of the intellectual dimensions of work, polyvalence, and multifunctionality of the worker, exemplified by the development of different skills and competences for the assessment of health needs of the individual, the family, and of collectivity, negotiations and decision-making in shared form ${ }^{(1)}$.

In this scenario occurs increased physical and mental workload ${ }^{(2)}$, in which new risks to health and worker safety, such as psychosocial risks, are added to those already existing in the working environment, with the potential to increase the prevalence of professional exhaustion, also referred to as burnout ${ }^{(3)}$. This is an emerging public health concern with repercussions in various areas of knowledge, such as: human resources management in health, health services management, workers' health, and social security. Professional exhaustion is a syndrome characterized by an increased frequency of feelings of emotional exhaustion and depersonalization, or of personal accomplishment reduced due to work $^{(3-4)}$.

The complex reality these nurses face nowadays encourages critical thinking in relation to the organization of health work, health care of nurses, and nursing human resources, and allows for an approximation of countries from Latin America and the Caribbean regarding environment problems and nursing working conditions. Investigating this subject is a priority of the National Agenda of Priorities in Health Research in Brazil, Latin America and the Caribbean, with regard to the restructuring of health work and human resources in health ${ }^{(5)}$.

The hypotheses of this study are as follows: professional exhaustion is present among family health nurses; the nurses have intention of leaving current work and even nursing; and that professional exhaustion correlates with a decrease in professional quality of care, intention of leaving current work, and nursing.

\section{OBJECTIVE}

To analyze how family health nurses assess quality of care, check if they have any intention of leaving their current job and nursing, estimate the prevalence of professional exhaustion, and analyze potential correlations among variables.

\section{METHOD}

\section{Ethical aspects}

This study was approved by the Research Ethics Committee of the School of Medical Sciences of the State University of
Campinas, having generated a Certificate of Presentation for Ethical Consideration. All participants read and signed two copies of the Informed Consent Form.

\section{Design, study site and period}

This is an observational, cross-sectional and correlational study, guided by the initiative Strengthening the Reporting of Observatinal Studies in Epidemiology (Strobe) with regard to the communication of the research ${ }^{(6)}$.

The study was conducted in Campinas, a large municipality in Brazil, considered a full manager of its municipal health system, and absorbing part of the demand of the region. Data collection was conducted in the second half of 2012.

\section{Population, inclusion and exclusion criteria}

The study population was defined from a list of 287 primary health care nurses, and 266 professionals were found. The following was considered as inclusion criterion: exercising nurse professional activity in one of the family health units that have a family health team; and the following as exclusion criteria: being absent from work, or being on license or vacation at the time of data collection. According to the eligibility criteria, 198 nurses accepted participating in the voluntary survey.

\section{Study protocol}

The instrument for data collection used to characterize nurses consisted of two parts: the first with questions related to personal and professional data; and the second with questions for assessing general perceptions about quality of care, sufficiency in the number of professionals and resources available for work, and questions to assess the intentions of leaving current work ${ }^{(7-10)}$ and leaving nursing ${ }^{(7,9-12)}$.

The perception of quality of care was assessed using a question with Likert type scale and the following score: 1 (very bad), 2 (bad), 3 (good), and 4 (very good) ${ }^{(7)}$. The sufficiency of professionals and material resources was evaluated by questions with dichotomous variables (yes, no).

Intention of leaving current work was examined by means of a question ("Put a mark along the line at the point that best describes your intention of leaving your current work in the next 12 months"), and the intention of leaving the nursing profession was examined by another question ("Put a mark along the line at the point that best describes your intention of leaving nursing in the next 12 months"). Both should be answered in visual analog scale from 0 (none) to $100 \mathrm{~mm}$ (a lot) ${ }^{(7)}$. These variables were considered outcome variables ${ }^{(6)}$ with regard to professional exhaustion in this research, as well as the quality of care.

The prevalence of professional exhaustion among professional nurses was assessed using the Maslach Burnout Inventory $(\mathrm{MBI})$, a specific version for health professionals, validated in Brazil by Tamayo in 1997 and used among hospital nurses ${ }^{(7)}$. The instrument measures the frequency of feelings expressing three dimensions of the syndrome: emotional exhaustion, depersonalization and reduction in personal accomplishment $t^{(4,7)}$, considered predictors $^{(6)}$ of the intention of leaving current work and nursing, and of the quality of care in this research. Its measurement scale is of Likert type, with the following score: 
(1) never, (2) rarely, (3) sometimes, (4) frequently, and (5) always $^{(7)}$. The higher the score, the higher the frequency of feelings of emotional exhaustion, depersonalization or personal accomplishment ${ }^{(4)}$.

\section{Analysis of results and statistics}

To decrease potential biases, of the 198 nurses who agreed to voluntarily participate in the survey, the instruments that were not completely filled with 30 professionals were excluded, which resulted in 168 eligible participants ${ }^{(6)}$, composing the sample. This number was a calculation basis for the tertile of each of the $\mathrm{MBI}$ subscales. There is no consensus in the literature on the analysis and interpretation of the $\mathrm{MBI}$. In this research, high levels of emotional exhaustion or depersonalization (third tertile), or low levels of professional accomplishment (first tertile), were considered professional exhaustion according to the criteria by Grunfeld et $\mathrm{al}^{(4)}$.

Not all survey respondents answered the questions corresponding to the variables: time since graduated, weekly work hours, intention of leaving current work, and intention of leaving nursing. The number of participants analyzed ${ }^{(6)}$ for each of these variables is presented in Table 3. The participants refused to answer the items in the $\mathrm{MBI}$ and correlated variables were excluded from correlational analyses, and the number of respondents is shown in Table 5.

The data were typed in Excel spreadsheet, double checked, and imported into the software Statistical Analysis System (SAS) version 9.2 for analysis. Combined averages of the $\mathrm{MBI}$ subscales were obtained in order to be correlated with the average of the variables: quality of care, intention of leaving current work, and intention of leaving nursing, as conducted by other authors ${ }^{(7)}$. For the correlation analysis between variables, we used Spearman's rank correlation coefficient, and $p \leq 0.05$. The reliability of the MBI subscales were tested through the criterion of internal consistency, and measured using Cronbach's alpha coefficient, where values higher than 0.60 were considered acceptable.

\section{RESUITS}

Table 1 presents personal and professional characteristics of the family health nurses. Most subjects in this research are women, single, with graduate studies in collective health, under the public workers' statute, and concentrating their work in one shift (Table 1).

Table 2 presents the nurses' perceptions on the quality of care and sufficiency of the amount of professionals and resources available for work. Most participants perceive quality of care as good and consider the number of professionals and resources available as inadequate (Table 2).

Table 3 presents descriptive measures of the variables: time since graduated, weekly work hours, intention of leaving current work, and intention of leaving nursing. The average weekly working hours is of 38.27, and there is intention of leaving current work and leaving nursing as well (Table 3 ).

In Table 4 are described the cut-off points obtained from the tertile, according to the distribution of scores attributed by the nurses to each of the MBI subscales.
Table 1 - Personal and professional characteristics of family health nurses, Campinas, São Paulo, Brazil, 2012 $(\mathrm{N}=198)$

\begin{tabular}{|c|c|c|}
\hline Variable & n* & $\%$ \\
\hline \multicolumn{3}{|l|}{ Sex } \\
\hline Female & 175 & 88.38 \\
\hline Male & 23 & 11.62 \\
\hline \multicolumn{3}{|l|}{ Marital status } \\
\hline Single & 90 & 45.45 \\
\hline Married & 84 & 42.42 \\
\hline Divorced or widowed & 21 & 10.61 \\
\hline No information & 3 & 1.52 \\
\hline \multicolumn{3}{|l|}{ Specialization Graduate Course } \\
\hline Public Health & 117 & 59.10 \\
\hline Other fields & 39 & 19.70 \\
\hline Does not have & 41 & 20.70 \\
\hline No information & 1 & 0.50 \\
\hline \multicolumn{3}{|l|}{ Graduated more than once } \\
\hline Yes & 17 & 8.59 \\
\hline No & 181 & 91.41 \\
\hline \multicolumn{3}{|l|}{ Employment Relationship } \\
\hline Under Public Workers' Statue & 191 & 96.46 \\
\hline Under CLT+ Regime & 3 & 1.52 \\
\hline No information & 4 & 2.02 \\
\hline \multicolumn{3}{|c|}{ Has another employment relationship } \\
\hline Yes & 19 & 9.60 \\
\hline No & 177 & 89.39 \\
\hline No information & 2 & 1.01 \\
\hline \multicolumn{3}{|l|}{ Work shift } \\
\hline Morning, afternoon or night & 109 & 55.05 \\
\hline Mixed & 83 & 41.92 \\
\hline No information & 6 & 3.03 \\
\hline
\end{tabular}

Note: *number of nurses; +Consolidation of Labor Laws.

Table 2 - Perceptions of family health nurses, Campinas, São Paulo, Brazil, $2012(\mathrm{~N}=198)$

\begin{tabular}{lcc}
\hline Variable & $\mathbf{n} *$ & $\mathbf{\%}$ \\
\hline & & \\
Perception of quality of care & 1 & 0.50 \\
$\quad$ Very bad & 26 & 13.13 \\
Bad & 154 & 77.78 \\
Good & 14 & 7.07 \\
Very good & 3 & 1.52 \\
No information & & \\
Adequate number of professionals & 34 & 17.17 \\
Yes & 162 & 81.82 \\
No & 2 & 1.01 \\
No information & & \\
Adequate resources & 10 & 5.05 \\
Yes & 187 & 94.44 \\
No & 1 & 0.51 \\
No information & & \\
\hline
\end{tabular}

Note: *number of nurses. 
Considering the cut-off points obtained (Table 4 ), $28.0 \%$ of the family health nurses showed high scores for emotional exhaustion, $32.1 \%$ for depersonalization, and $38.7 \%$ showed low scores for personal accomplishment, which configures professional exhaustion. It was found that $37.5 \%$ of the nurses showed moderate scores for emotional exhaustion, $33.9 \%$ for depersonalization and $33.3 \%$ for personal accomplishment. It was found that $34.5 \%$ of the nurses showed low scores for emotional exhaustion, $33.9 \%$ for depersonalization, and $28 \%$ displayed high scores for personal accomplishment. In relation to the internal consistency of the $\mathrm{MBI}$, Cronbach's alpha coefficient resulted in 0.86 for emotional exhaustion, 0.66 for depersonalization and 0.72 for personal accomplishment.

The correlations between MBI subscales were analyzed by comparing them to the variables: quality of care, intention of leaving current work, and intention of leaving nursing. The correlations are presented in Table 5 . It is worth highlighting the presence of five significant correlations, with moderate and low magnitudes (Table 5).

\section{DISCUSSION}

The equivalent proportion of nine female nurses for every male nurse (Table 1) highlighted the intense feminization of the profession ${ }^{(13)}$. The predominance of singles in the sample (Table 1) probably decreased the impact of conflict experiences arising from professional responsibilities and reference to the collective in relation to economic and emotional responsibilities of married professionals who have children on the family group ${ }^{(14-15)}$.

Most participants were affiliated with the city prefecture by Public Workers' Statute, having been approved by public sector recruitment on the basis of examinations and degrees for receiving a position, and also had access to a Specialization Graduate Course in the field of Public Health (Table 1). Interestingly, 8.6\% of nurses were graduated in more than one field (Table 1), pointing to the duplicity of professional formation in part of the family health nurses. The average "time since graduated" of participants was of 10.6 years (Table 3), with variation from 2 to 35 years, which indicated the coexistence of different generations of nurses in the practice of nursing within the family health strategy.

In the municipality studied, the work shift could be mixed, with lunch break, but most nurses predominantly concentrated their daily journey in one shift (Table 1). Although it was observed that most participants had only one employment relationship
(Table 1), which is desirable considering the construction of the bond with the collective and the recognition of the nursing work environment as stressful, it was found that the average weekly work hours, including other possible employment relationships, was superior to the 30 hours per week (Table 3 ) historically desired by nursing professionals.

One study showed that, in order to tolerate excess work hours over time, professionals often register their presence in the workplace without showing good performance during the whole period because they were emotionally exhausted and unmotivated, configuring presenteeism ${ }^{(16)}$. As this phenomenon occurs, it impacts on quality of care and represents an important challenge for managers of health services and health human resources.

In this research, $86.15 \%$ of family health nurses assessed the quality of care as good or very good, and $13.84 \%$ assessed it as bad or very bad (Table 2). On the other hand, most of the family health nurses considered the number of professionals and resources available for conduction of care as inadequate (Table 2). It is important to consider that the perception of quality of care in primary health care brings with it an enormous degree of subjectivity and depends 
on the conception of the health care model in APS adopted in the municipality, which is limited by the structure of the health service and the financing available and managed at local level.

In relation to the care model, Mendes explains there are different decoding of APS to be considered: (1) as a selective primary care offered to poor people in poor regions, to whom is exclusively offered a set of low-cost technologies without the possibility of referrals and care levels of higher technological density; (2) as a primary level of access to the health system, emphasizing the way of organizing the entryway so that it meets the demands of the population for the most common health problems and minimizes economic costs; (3) as a an organization strategy of the health care system in the Health Care Network (RAS) and a way of organizing all of the system resources in order to satisfy the demands of the population ${ }^{(17)}$.

Regarding the perception of quality of care, the expression is associated to security aspects of attendance, quantity and qualification of professionals, ambience wherein care is conducted. In this study, as most nurses assessed human and material resources as inadequate and still considered the quality of care as good and very good (Table 2), we can infer that assessment of the APS was based on the recognition of the model of primary care as selective, requiring fewer professionals and fewer resources ${ }^{(17)}$.

Although the new Brazilian National Primary Health Care Policy has established criteria for the organization of work processes in the APS with emphasis on ESF, according to Mendes, innovation is far from effectively being consolidated in practice, as structural conditions were not provided in order for that to happen, and cultural, technical and operational aspects from the conceptions of selective APS and APS as primary level of access still get merged with hazy distinctions ${ }^{(17)}$. On the other hand, the achievements obtained in health are not cumulative nor permanent, since according to the political decisions adopted in the three levels of government, what was already achieved always has the risk of being lost.

This study witnessed intention of leaving the job among family health nurses, whose average obtained was of $28.40 \mathrm{~mm}$ in the visual analog scale from 0 to $100 \mathrm{~mm}$ (Table 3). This was higher than the average found among intensive therapy nurses ${ }^{(7)}$. The compared result suggests that dissatisfaction with the professional practice environment is higher among ESF nurses than among nurses who work in intensive therapy environments. This evidence can be associated with the distribution of resources in the public health system, whose priority in a situation of insufficient funding is in general directed to tertiary health care, which includes intensive therapy services with focus on diagnostic technology and treatment of diseases, thereby reducing resources for primary health care.

Although there is a consensus that APS has the potential to solve $80 \%$ or more of the health problems of the population, this resolution is not effective in the conservative practice of primary care, and obscures its complexity in relation to care and management strategies for solving health problems ${ }^{(17)}$, impairing the overcoming of selective APS practice.

To tolerate the risks of work situations, as in the case of a primary care environment turned precarious, professionals often use the strategy of denying or trivializing these risks due to fear of unemployment or being disqualified and having their professional development or functional trajectory harmed, compromising the moral integrity of these professionals ${ }^{(18)}$. In this situation, when exposure to health risks and the uncertainty present in the working environment come to the mind of the nurse, the intention of leaving current work comes as well.

According to Fertonani et al., when considering the different understandings about the health care model, in reality persists the model focused on treating diseases, from biologic body care, in detriment of the model that emphasizes integrality ${ }^{(19)}$. In addition, deficits in the formation of family health teams and the precariousness of the work relations and conditions ${ }^{(19)}$ consolidate the practice of selective primary care ${ }^{(17)}$. In this context, nurses' frustation can intensify, increasing their negative perception of the professional environment, decreasing their professional performance and increasing their intention of leaving current work $^{(9)}$, this being considered a strong predictor of staff turnover ${ }^{(10)}$.

A study with ESF professionals highlights employment turning precarious and poor working conditions as the main causes of turnover $^{(9)}$. Individually, turnover is harmful to workers' health due to increased workload for those who continue exercising their professional practice in the institution, as they are usually forced to increase work-pace in order to maintain the previous productivity levels, adapt to longer week hours and, occasionally, being entrusted to the supervision of new workers ${ }^{(12)}$.

In relation to the health team, turnover can result in loss of team cohesion and familiarity between its members and lead to episodes of intolerance and aggression against supervisors, subordinates and peers, where this deterioration in organizational environment may become a reason for future abandonment of the profession ${ }^{(11)}$. High levels of staff turnover at institutional level generally implies reduction in the quality of healthcare service and involves problems of organization as well as direct and indirect costs ${ }^{(9)}$, causing damage to the institution's image ${ }^{(20)}$, hindering the organization of the APS in $\operatorname{RAS}^{(17)}$.

This study also highlighted the intention of leaving nursing (Table 3), with a value that is close to that found among intensive care nurses ${ }^{(7)}$. The reason considered the most relevant for the intention of abandoning nursing is discontent with the working atmosphere ${ }^{(12)}$. The studies cited and the findings of this research show that the negative perception of the professional practice environment is associated with dissatisfaction, future prospects of abandoning the profession, and can be considered an indicator that anticipates the leaving, as studied in countries that describe the shortage of professionals in the work market ${ }^{(8)}$.

Regarding MBI usage, Cronbach's alpha values indicated that the three subscales showed internal consistency in the work locus of family health nurses. According to the criteria by Grunfeld et al., in this study, 28 to $38.7 \%$ of these nurses experienced professional exhaustion. The estimate of burnout prevalence deserves visibility and confrontation, and can contribute to the construction of indicators for quality of service and life of workers.

Significant correlation between emotional exhaustion and intention to leave the current job was witnessed, corroborating results already seen between primary care ${ }^{(20)}$ and intensive care professionals $^{(7)}$. It was also evidenced significant correlation between emotional exhaustion and intention of leaving nursing. Hence, emotional exhaustion can be pointed as a predictor of intention of leaving nursing in this study. In the scenario of 
resistance and consolidation of SUS, researchers and managers must worry about ways to prevent nurses from abandoning their profession, as they are professionals with the skills and abilities that are desirable for conducting this health policy.

Two other significant correlations observed (Table 5) highlighted the reduction of personal accomplishment as a predictor of decreased quality of care and of the intention to leave the current job. Depersonalization was singled out as the only predictor of the intention of leaving the current job. Evidences of professional exhaustion among family health nurses help explain problems related to quality of care, the care model ${ }^{(17,19)}$, presenteeism $^{(16)}$ and staff turnover ${ }^{(9)}$.

It is advisable to perform permanent education and stimulate the recognition of existing health care models and care models that are to be constructed ${ }^{(19)}$, in order to scale the number of professionals to the real population connected to the health unit. It is imperative that political participation of nurses be encouraged, in order to contribute for the identification and transformation of the structures that prevent SUS of being effectively conducted. Political omission can mean maintaining a non-desirable situation, the loss of what has already been achieved, and the impracticality of SUS to future generations. As recognizes the Brazilian Nursing Association (ABEn): health is democracy, and vice versa. Democracy requires political participation of all social groups, especially women.

\section{Study limitations}

Regarding study limitations, the absence of family health nurses not under Public Workers' Statute, hired for a set time, with effective perspective of extinction of the work contract in the short-term, was considered a potential selection bias ${ }^{(6)}$. It is noteworthy that data collection was conducted in a context of political instability in the municipality, which had successive depositions of mayors in 2012, which influenced negatively in the adhesion of these nurses to participating in the research.

\section{Contributions to the field of Nursing}

This research contributes to the science of nursing by providing information to support interventions in the environment of professional practice and for the construction of evaluation indicators of health services and human resources in nursing.

\section{CONCLUSION}

This study observed that the majority of family health nurses are female, assess the quality of work as good at the same time they recognize the inadequacy of human and material resources, pointing to the practice of a predominantly selective model of primary health care. Family health nurses experience the syndrome of professional exhaustion, which in this study was considered as a predictor of decreased quality of care, intention of leaving the current job, and intention of leaving nursing. Despite the limitations described, the hypotheses of this investigation were confirmed and the study denounces negative aspects of the work environment of family health nurses in the scenario studied, allowing comparison with other municipalities in similar situations, including other countries of Latin America and the Caribbean.

\section{REFERENCES}

1. Peduzzi M. Trabalho educação na saúde: ampliação da abordagem de recursos humanos. Ciênc Saúde Colet[Internet]. 2013[cited 1016 Jul 31];18(6):1539-41. Available from: http://www.scielo.br/pdf/csc/v18n6/05.pdf

2. Pires DEPP, Machado RR, Soratto J, Schere MA, Gonçalves ASF, Trindade LL. Cargas de trabalho da enfermagem na saúde da família: implicações no acesso universal. Rev Latino-Am Enfermagem[Internet]. 2016[cited 2017 Feb 18];24:e2682. Available from: http:// www.scielo.br/pdf/rlae/v24/pt_0104-1169-rlae-0992-2682.pdf

3. Rodriguez SYS, Carlotto SM. Predictors of Burnout Syndrome in psychologists. Est Psicol Campinas[Internet]. 2017[cited 1017 Feb 18];34(1)I141-150. Available from: http://www.scielo.br/pdf/estpsi/v34n1/0103-166X-estpsi-34-01-00141.pdf

4. Grunfeld E, Whelan TJ, Zitzelsberger L, Willan AR, Montesanto B, Evans WK. Cancer care workers in Ontario: prevalence of burnout, job stress and job satisfaction. CMJA[Internet]. 2000[cited 1016 Jul 31];163(2):166-9. Available from: http://www.cmaj. ca/content/163/2/166.long

5. Reveiz I, Chapman E, Flórez CEP, Torres R. Prioridades de investigación en políticas y sistemas de salud centradas em lós recursos humanos em salud. Rev Panam Salud Publica[Internet]. 2013[cited 1016 Jul 31];34(5):295-303. Available from: http://www.scielosp. org/pdf/rpsp/v34n5/a01v34n5.pdf

6. Malta M, Cardoso LO, Bastos FI, Magnanini MMF, Silva CMFP. STROBE initiative: guidelines on reporting observational studies. Rev Saúde Pública[Internet]. 2010[cited 1016 Jul 31];44(3):559-65. Available from: http://www.scielo.br/pdf/rsp/v44n3/en 21.pdf

7. Panunto MR, Guirardello EB. Professional nursing practice: environment and emotional exhaustion among intensive care nurses. Rev Latino-Am Enfermagem[Internet]. 2013[cited 1016 Jul 31];21(3):765-72. Available from: http://www.scielo.br/pdf/rlae/ v21n3/0104-1169-rlae-21-03-0765.pdf

8. Cortese CG. Predictors of critical care nurses' intention to leave the unit, the hospital, and the nursing profession. Open J Nurs[Internet]. 2012[cited 1016 Jul 31];(2):311-26. Available from: http://file.scirp.org/pdf/OJN20120300024 12844001.pdf

9. Medeiros CCRG, Junqueira ÁGW, Schwingel G, Carreno I, Jungles LAP, Saldanha OMFL. A rotatividade de enfermeiros e médicos: um impasse na implementação da Estratégia de Saúde da Família. Ciênc Saúde Colet[Internet]. 2010 [cited 1016 Jul 
31];15(Supl-1):1521-31. Available from: http://www.scielo.br/pdf/csc/v15s1/064.pdf

10. O'Brien-Pallas L, Griffin P, Shamian J, Buchan J, Duffield C, Hughes F, et al. The impact of nurse turnover on patient, nurse, and system outcomes: a pilot study and focus for a multicenter international study. Policy Polit Nurs Pract[Internet]. 2006[cited 1016 Jul 31];7(3):169-79. Available from: http://www.pubfacts.com/detail/17071704/ The-impact-of-nurse-turnover-on-patient-nurse-and-system-outcomes-a-pilot-study-and-focus-for-a-mult

11. Estryn-Béhar M, Le Nézet O, Van der Heijden BIJM, Oginska H, Camerino D, Conway PM, et al. Inadequate teamwork and burnout as predictors of intent to leave nursing according to seniority. Stability of associations in a one-year interval in the European NEXT Study. Ergon IJE\&HF[Internet]. 2007[cited 1016 Jul 31];29(3-4):225-33. Available from: http://www.academia.edu/17684325/ Inadequate_Teamwork_and_Burnout_as_Predictors_of_Intent_to_Leave_Nursing_According_to_Seniority._Stability_of_Associations in_a_One-year_Interval_in_the_European_NEXT_Study

12. Hayes LJ, O'Brien-Pallas L, Duffield C, Shamian J, Buchan J, Hughes F, et al. Nurse turnover: a literature review - an update. Int J Nurs Stud[Internet]. 2012[cited 1016 Jul 31];49(7):887-905. Available from: https://www.researchgate.net/ publication/7861759_Nurse_turnover_A_literature_review-An_update

13. Souza MMG, Mandu ENT, Elias AN. Perceptions of nurses regarding their work in the family health. Texto Contexto Enferm[Internet]. 2013[cited 1016 Jul 31];22(3):772-9. Available from: http://www.scielo.br/pdf/tce/v22n3/en_v22n3a25.pdf

14. Carreiro GSP, Ferreira Filha MO, Lazarte R, Silva AO, Dias MD. O processo de adoecimento mental do trabalhador da Estratégia Saúde da Família. Rev Eletron Enferm[Internet]. 2013[cited 1016 Jul 31];15(1):146-55. Available from: https://www.fen.ufg.br/ fen_revista/v15/n1/pdf/v15n1a17.pdf

15. Yamaguchi Y, Inoue T, Harada H, Oike M. Job control, work-family balance and nurses' intention to leave their Professional and organization: a comparative cross-seccional survey. Int J Nurs Stud[Internet]. 2016[cited 2017 Feb 18];64(2016):52-62. Available from: http://www.journalofnursingstudies.com/article/S0020-7489(16)30150-X/pdf

16. Umann J, Guido LA, Grazziano ES. Presenteeism in hospital nurses. Rev Latino-Am Enfermagem[Internet]. 2012 [cited 1016 Jul 31];20(1):159-66. Available from: http://www.scielo.br/pdf/rlae/v20n1/21.pdf

17. Mendes EV. A construção social da atenção primária à saúde[Internet]. Brasília: Conselho nacional de Secretários de Saúde - Conass; 2015[cited 1016 Jul 31];193p. Available from: http://www.conass.org.br/biblioteca/pdf/A-CONSTR-SOC-ATEN-PRIM-SAUDE.pdf

18. Dalmolin GL, Lunardi VL, Barlem ELD, Silveira RS. Implications of moral distress on nurses and its similarities with burnout. Texto Contexto Enferm[Internet]. 2012[cited 1016 Jul 31];21(1):200-8. Available from: http://www.scielo.br/pdf/tce/v21n1/en_a23v21n1.pdf

19. Fertonani HP, Pires DEP, Biff D, Scherer MDA. The health care model: concepts and challenges for primary health care in Brazil. Ciênc Saúde Colet[Internet]. 2015[cited 1016 Jul 31];20(6):1869-78. Available from: http://www.scielo.br/pdf/csc/v20n6/en_14138123-csc-20-06-1869.pdf

20. Mata C, Machado S, Moutinho A, Alexandra D. PreSBurn study: prevalence of burnout syndrome in primary care professionals. Rev Port Med Geral Fam[Internet]. 2016[cited 2017 Feb 18];32(3). Available from: http://www.scielo.mec.pt/pdf/rpmgf/v32n3/ v32n3a04.pdf 